dr hab. Piotr Chomik, prof. UwB

Biblioteka Uniwersytecka im. Jerzego Giedroycia

chop@uwb.edu.pl

\title{
HISTORIA I WSPÓŁCZESNOŚĆ BIBLIOTEKI UNIWERSYTECKIEJ IM. JERZEGO GIEDROYCIA
}

\author{
THE JERZY GIEDROYC UNIVERSITY LIBRARY \\ - THE PAST AND THE PRESENT
}

\begin{abstract}
Abstrakt
Celem artykułu było przedstawienie dziejów i czasów współczesnych Biblioteki Uniwersyteckiej im. Jerzego Giedroycia. W artykule zwrócono uwagę na trudności, z jakimi borykała się Biblioteka dawniej i z jakimi boryka się po dzień dzisiejszy. Opisano rozwój księgozbioru bibliotecznego. Wskazano na ważny aspekt działalności biblioteki, jakim jest działalność kulturalna i popularyzująca naukę. Opisano rozwój usług i narzędzi bibliotecznych w Bibliotece Uniwersyteckiej.
\end{abstract}

Słowa kluczowe: Biblioteka Uniwersytecka im. Jerzego Giedroycia, historia biblioteki, współczesna biblioteka, biblioteka akademicka, biblioteka uniwersytecka.

\begin{abstract}
The aim of the article is to present the history and present circumstances of the Jerzy Gieroyc University Library. The article draws attention to the difficulties faced by the Library in the past and those it faces today. It also describes the development of the Library's collection as well as its services and tools. The popularization of culture and science, which is an important aspect of the Library's activity, is emphasized.
\end{abstract}

Keywords: The Jerzy Giedroyc University Library, library history, contemporary library, academic library, university library. 
Historia Biblioteki Uniwersyteckiej rozpoczyna się 1 października 1968 r. wraz z utworzeniem Filii Uniwersytetu Warszawskiego w Białymstoku. Początkowo Biblioteka mieściła się w obecnym budynku Wydziału Prawa przy ul. A. Mickiewicza 1, gdzie dysponowała pomieszczeniami o powierzchni $475 \mathrm{~m}^{2}$ oraz czytelnią z 20 miejscami dla użytkowników. Biblioteka zatrudniała sześciu bibliotekarzy. Księgozbiór w chwili powstania Biblioteki liczył około 60 tys. woluminów. W pierwszych latach działalności nastąpił dynamiczny wzrost liczby pozyskanych zbiorów, głównie dzięki darom przekazanym przez Bibliotekę Uniwersytecką w Warszawie i inne biblioteki krajowe oraz osoby prywatne. W 1973 r. Biblioteka posiadała księgozbiór w liczbie 120 tys. woluminów. Cztery lata później liczba ta wzrosła do 200 tys. przy rocznym wpływie 30 tys. woluminów ${ }^{1}$.

W 1976 r. ówczesny kierownik Biblioteki Filii Uniwersytetu Warszawskiego, wówczas magister (a obecnie profesor) Piotr Wróblewski pisał: „trudności z którymi boryka się Biblioteka związane są [...] z brakiem miejsca na gromadzenie i udostępnianie zbiorów. Jeżeli Biblioteka nie otrzyma dodatkowego miejsca przestanie funkcjonować i to już wkrótce"2. Słowa te są aktualne również dzisiaj, z tym, że oczywiście zaprzestanie funkcjonowania Bibliotece nie grozi.

$\mathrm{Na}$ początku lat 80. pojawił się temat budowy odpowiedniego gmachu dla Biblioteki. Zrezygnowano jednak z tego pomysłu, kiedy w 1982 r. ówczesny Minister Nauki, Szkolnictwa Wyższego i Techniki wydał decyzję o przekazaniu na jej potrzeby części pomieszczeń powstającego Zakładu Elektronicznej Techniki Obliczeniowej (ZETO) przy ul. Skorupskiej 9. Dokończenie budowy i adaptacja budynku trwały sześć lat. Na początku lat osiemdziesiątych Biblioteka przyjęła 150 tys. woluminów darów - głównie dubletów, przekazanych przez Bibliotekę Uniwersytecką w Warszawie oraz dalszych 50 tys. woluminów od różnych bibliotek krajowych i osób prywatnych. W 1984 r. zbiory Biblioteki liczyły ogółem 415503 woluminy. W kolejnych latach roczne wpływy kształtowały się na poziomie 11-13 tys. jednostek ewidencyjnych, prowadzono również systematyczną selekcję zbiorów poprzez ubytkowanie druków zbędnych ${ }^{3}$.

Nowa siedziba nie zaspokajała podstawowych potrzeb lokalowych. W konsekwencji po przeprowadzce Biblioteki do budynku ZETO

1 [Dziesięć] X lat Uniwersytetu w Białymstoku. Białystok 2008, s. 343.

2 P. Wróblewski: Jajogłowi pustogłowi. Wołanie o światło: korespondencja: $w$ bibliotekach. „Kontrasty” 1976, nr 6, s. 63.

3 Tamże. 
o powierzchni około $2048 \mathrm{~m}^{2}$, w 1988 r. Oddział Opracowania Wydawnictw Ciągłych wraz $\mathrm{z}$ czytelnią pozostał $\mathrm{w}$ starym budynku przy ul. Mickiewicza 1.

Pod koniec lat 90. warunki lokalowe Biblioteki ponownie uległy pogorszeniu. Oddział Czasopism został zmuszony do opuszczenia dotychczasowych pomieszczeń o powierzchni $390 \mathrm{~m}^{2}$ i przeniesienia się na ul. M. Skłodowskiej-Curie 14, do lokalu o powierzchni $115 \mathrm{~m}^{2}$.

Swoje pomieszczenia na rzecz ZETO straciły: Wypożyczalnia Międzybiblioteczna, Oddziały Opracowania Alfabetycznego i Opracowania Rzeczowego Zbiorów, sekretariat oraz dyrekcja.

Całkowita powierzchnia zajmowana przez Bibliotekę w dwóch budynkach wynosiła w tym czasie $1830 \mathrm{~m}^{2}$, a czytelnicy korzystali z 84 miejsc w trzech czytelniach. W takiej sytuacji budowa nowego gmachu stawała się coraz bardziej nagląca. W 1997 r. księgozbiór liczył 403536 woluminów .

Z chwilą powstania Uniwersytetu w Białymstoku (UwB) w 1997 r. radykalnie zmieniło się nastawienie władz uczelni do kwestii budowy i nowy gmach Biblioteki stał się sprawą priorytetową. Ministerstwo Edukacji Narodowej przychylnie odniosło się do tej inicjatywy, a władze miasta umożliwiły Uczelni zakup po preferencyjnych cenach działki w centrum Białegostoku, znajdującej się tuż obok głównego budynku Uniwersytetu. Kamień węgielny pod budowę nowej Biblioteki Uniwersyteckiej przy ul. M. Skłodowskiej-Curie 14A wmurowano 13 października 1999 r. Po 2000 r. Biblioteka otrzymała w darze kilka znacznych księgozbiorów przekazanych przez prywatnych darczyńców lub rodziny zmarłych pracowników UwB, m.in.: prof. Renaty Mayenowej - około 2,5 tys. woluminów, prof. Mieczysława Basaja - około 2,5 tys. woluminów, dra Zbigniewa Suszczyńskiego (pracownika Wydziału Filologicznego UwB) - około 2,5 tys. woluminów, Anny Markowej (białostockiej poetki) - około 1 tys. woluminów, Sióstr Urszulanek - około 1 tys. woluminów, Fundacji Ekonomia i Środowisko około 1,6 tys. woluminów oraz Domu Emigracji Rosyjskiej w Moskwie około 600 woluminów. W 2005 r. zbiory Biblioteki liczyły 503151 woluminów, w tym druki zwarte i ciągłe (seryjne) - 429643 woluminy, czasopisma 60537 woluminów, zbiory specjalne - 12971 woluminów.

Budowa gmachu zajęła prawie sześć lat i wreszcie 8 marca 2005 r. rozpoczęła się przeprowadzka Biblioteki do nowej siedziby.

Otwarcie Biblioteki Uniwersyteckiej, która otrzymała imię Jerzego Giedroycia, nastąpiło 24 czerwca 2005 r. Nowy budynek Biblioteki

4 Tamże, s. 343-344. 
Uniwersyteckiej miał siedem kondygnacji, w tym jedną podziemną. Jego kubatura wynosiła według projektu $34802 \mathrm{~m}^{3}$, z czego powierzchnia użytkowa to $8324 \mathrm{~m}^{2}$. Przewidziano, że magazyny pomieszczą 860 tys. woluminów, a czytelnicy będą mieli do dyspozycji 327 miejsc w czytelniach i pokojach pracy indywidualnej. Nowy budynek oraz dostępne w nim przestrzenie otworzyły przed Biblioteką Główną nowe perspektywy. Umożliwiły nie tylko rozwijanie prowadzonej działalności, ale także realizacje kolejnych projektów i zaoferowanie użytkownikom nowych usług. Wśród rozpoczętych w tym czasie inicjatyw, takich jak: rozliczne wystawy, spotkania czy wykłady, warto zwrócić uwagę na zainaugurowany w lutym 2006 r. cykl „Podlaskie Forum Bibliotekarzy”, którego celem jest integracja środowiska bibliotekarskiego Białegostoku. Przybywają na nie pracownicy bibliotek naukowych, publicznych i szkolnych oraz studenci bibliotekoznawstwa, by wysłuchać wykładów wygłaszanych przez zapraszanych gości oraz wziąć udział $\mathrm{w}$ dyskusjach na tematy zawodowe. Inna ważna inicjatywa rozpoczęta w 2008 r., to seria spotkań „Podlasie w badaniach naukowych”, popularyzująca wśród mieszkańców Białegostoku badania prowadzone przez pracowników naukowych UwB, które dotyczą naszego regionu.

W czerwcu 2007 r. zorganizowano pierwszą konferencję bibliotekarską, poświęconą zagadnieniu kultury organizacyjnej w bibliotece. Sukces tej pierwszej konferencji pociągnął za sobą organizowanie kolejnych, na których poruszano takie tematy jak: marketing wewnętrzny (2009), bibliotekarstwo uczestniczące (2011), deregulacja zawodu (2013), spadek liczby czytelników (2015) czy fundraising biblioteczny $(2017)^{5}$.

Od 2007 r. Biblioteka Uniwersytecka jest koordynatorem projektu Podlaskiej Biblioteki Cyfrowej (PBC), realizowanego przez Konsorcjum Bibliotek Naukowych Miasta Białegostoku. Od 2009 r. zasoby PBC są dostępne w Europeanie, co stanowi dobrą promocję regionu.

Obok działalności naukowo-kulturalnej dbano również o poszerzanie wachlarza usług i zapewnianie kolejnych udogodnień dla użytkowników. W 2009 r. w ramach struktur Biblioteki rozpoczęło działalność Centrum Dokumentacji Europejskiej.

W maju 2010 r. otwarto Czytelnię z Wolnym Dostępem do Zbiorów. Zapewniała ona 88 miejsc dla czytelników oraz około 50 tys. egzemplarzy wyselekcjonowanego księgozbioru.

5 Zob.: H. Brzezińska-Stec: Biblioteka Uniwersytecka im. J. Giedroycia w Białymstoku w nowym gmachu - perspektywy pięcioletnich doświadczeń. „Bibliotheca Nostra” 2011, nr 2(24), s. 56-57. 
We wrześniu 2011 r. oddano dodatkowo do użytku Czytelnię Filologiczną, również z wolnym dostępem do półek, która zajęła IV piętro. $\mathrm{Na}$ obydwu piętrach Wolnego Dostępu, połączonych wewnętrzną klatką schodową, znalazło się w sumie około 100 tys. książek. W tym samym roku ruszył katalog centralny obejmujący wszystkie biblioteki wydziałowe, co znacznie ułatwiło korzystanie z zasobów Systemu Biblioteczno-Informacyjnego. Trzy lata później uruchomiono eCzytelnię, zawierającą cyfrowe kopie podręczników oraz innych często wykorzystywanych tytułów do skorzystania na miejscu.

W 2014 r. nastąpiło otwarcie Repozytorium Uniwersytetu w Białymstoku (RUB) stanowiącego ważny czynnik wspomagający rozwój nauki w środowisku akademickim.

W 2011 r. Biblioteka Uniwersytecka otrzymała część spuścizny po Ryszardzie Kaczorowskim, Ostatnim Prezydencie Polski na Uchodźstwie. Były to nie tylko książki z jego kolekcji (ponad 700 pozycji z archiwum Prezydenta trafiło do kolekcji Biblioteki w 2009 r.), ale i warszawski gabinet oraz różnorodne artefakty i memorabilia. W listopadzie $2011 \mathrm{r}$. nastąpiło uroczyste otwarcie Gabinetu Ryszarda Kaczorowskiego, przy współudziale Karoliny Kaczorowskiej, ulokowanego w Czytelni Ogólnej na drugim piętrze.

W listopadzie 2014 r. podpisano umowę przedwstępną o sprzedaży budynku bibliotecznego wraz z przyległym budynkiem rektoratu, w związku z ukończeniem budowy części uniwersyteckiego kampusu, zlokalizowanego przy ul. Ciołkowskiego 1 oraz przeniesieniem się do niego trzech wydziałów. Biblioteka Uniwersytecka po dziesięciu latach użytkowania opuściła gmach, który od października 2015 r. przejęła Książnica Podlaska im. Łukasza Górnickiego w Białymstoku

Obecnie zbiory biblioteki liczące ponad 600 tys. woluminów znalazły swoje miejsce w kilku nowych lokalizacjach. Kolekcja Humanistyczna licząca 138024 woluminy jest udostępniana w dawnym budynku Instytutu Matematyki przy ul. Akademickiej 2, w formie prezencyjnej (4 czytelnie dziedzinowe) i wypożyczeń krótkoterminowych. W tym budynku mieszczą się również: Repozytorium Uniwersytetu w Białymstoku, Centrum Dokumentacji Europejskiej, Pracownia Digitalizacji z Podlaską Biblioteką Cyfrową oraz Zbiory Specjalne. Czytelnia Ogólna Biblioteki Uniwersyteckiej znajduje się w kampusie, w budynku Wydziału Chemii,

6 Tamże.

7 Uniwersytet w Białymstoku 1997-2017. Białystok 2018, s. 553. 
tam też funkcjonuje Wypożyczalnia oraz Oddział Informacji Naukowej z czytelnią. W kampusie znalazły też swoje miejsce najczęściej wykorzystywane zbiory biblioteczne - blisko 70 tys. woluminów wydawnictw zwartych oraz 45 tys. woluminów czasopism. Dodatkowo zostały utworzone magazyny zewnętrzne na zbiory rzadziej wykorzystywane. Oddziały zajmujące się pracami wewnętrznymi funkcjonują we wszystkich (czterech) budynkach kampusu.

Budowa nowego gmachu Biblioteki Uniwersyteckiej w kampusie rozpoczęła się wiosną 2019 r., a jej zakończenie przewidziane jest na 2020 r.

Wciąż nierozwiązana sytuacja lokalowa nie przeszkadza jednak w dalszym rozwoju Biblioteki, która wciąż powiększa swoje zbiory. Dzięki współpracy $\mathrm{z}$ wydziałami UwB coraz szersza jest lista elektronicznych baz naukowych, co umożliwia pracownikom naukowym UwB dostęp do najnowszych osiągnięć badawczych w ich dyscyplinach naukowych. Od początku 2018 r. na stronie internetowej Biblioteki dostępna jest dla wszystkich multiwyszukiwarka naukowa. Wprowadzono też inne udoskonalenia m.in. regulowanie płatności bibliotecznych poprzez bankowość elektroniczną, dostępne od jesieni $2018 \mathrm{r}$.

Rozwijamy wciąż działalność Repozytorium UwB, naszym oczkiem w głowie jest Gabinet Ryszarda Kaczorowskiego Ostatniego Prezydenta RP na Uchodźstwie. Biblioteka nadal organizuje konferencje naukowe, coroczne spotkania naukowe dotyczące Otwartego Dostępu do Nauki. Kontynuujemy cykl „Podlasie w badaniach naukowych”, w ramach którego odbyło się już ponad 50 wykładów. Od 2017 r. organizujemy też z powodzeniem Dzień Książki Akademickiej i Naukowej, czyli targi książki połączone z promocjami wydawnictw naukowych i popularnonaukowych związanych $\mathrm{z}$ naszym regionem.

Pracownicy Biblioteki nieustannie podnoszą swoje kwalifikacje, uczestniczą też w konferencjach naukowych w Polsce i za granicą. W ciągu ostatnich 10 lat, wydali 80 publikacji z zakresu bibliotekoznawstwa i informacji naukowej oraz nauk humanistycznych.

W 2014 r. Biblioteka nawiązała kontakt z dyrektorami Bibliotek Sieci Pogranicza. W ramach tej sieci współpracujemy z Biblioteką Baranowickiego Uniwersytetu Państwowego z Białorusi, szczególnie blisko współpracujemy także z Biblioteką Uniwersytetu Grodzieńskiego Janki Kupały, czy Fundamentalną Biblioteką Białoruskiego Uniwersytetu Państwowego w Mińsku.

Dzisiaj Bibliotekę Uniwersytecką tworzą wszystkie biblioteki Systemu Biblioteczno-Informacyjnego UwB. Część podległą dyrektorowi BU 
stanowią Biblioteka Główna oraz biblioteki specjalistyczne: ekonomiczna, humanistyczno-społeczna, pedagogiczna i prawnicza. Pracuje w nich 90 osób. W całym Systemie Biblioteczno-Informacyjnym Uniwersytetu w Białymstoku zatrudnionych jest 100 osób.

Obecnie zbiory Biblioteki liczą ponad 600 tys. woluminów książek, czasopism i zbiorów specjalnych, a cały System Biblioteczno-Informacyjny zbliża się do $1 \mathrm{mln}$ woluminów. Prenumerujemy 137 tytułów czasopism krajowych i 10 zagranicznych oraz 12 specjalistycznych baz naukowych dostępnych online, które wraz z Wirtualną Biblioteką Nauki w ostatnim roku akademickim odnotowały blisko $4 \mathrm{mln}$ odwiedzin. Czytelnie i wypożyczalnie odwiedza rocznie ponad 14 tys. użytkowników, a łączna liczba udostępnień osiągnęła ponad 33 tys. woluminów. Wciąż rozwijamy bazy własne, realizujemy nowe projekty finansowane ze środków ministerialnych, $\mathrm{z}$ dużym zaangażowaniem prowadzimy serwisy $\mathrm{w}$ mediach społecznościowych. Wszystko to potwierdza, że Biblioteka Uniwersytecka im. Jerzego Giedroycia stanowi istotne ogniwo w procesie naukowo-dydaktycznym Uniwersytetu w Białymstoku, wsparte bogatym doświadczeniem zdobytym przez ponad 50 lat funkcjonowania.

\section{Bibliografia}

1. Brzezińska-Stec H.: Biblioteka Uniwersytecka im. J. Giedroycia w Białymstoku w nowym gmachu - perspektywy pięcioletnich doświadczeń. „Bibliotheca Nostra" 2011, nr 2(24), s. 50-60.

2. [Dziesięć] X lat Uniwersytetu w Białymstoku. Białystok 2008.

3. Uniwersytet $w$ Białymstoku 1997-2017. Białystok 2018.

4. Wróblewski P.: Jajogłowi pustogłowi. Wołanie o światło: korespondencja: $w$ bibliotekach. „Kontrasty” 1976, nr 6, s. 61-63. 